\title{
PENGARUH KERAGAMAN PRODUK TERHADAP KEPUASAN PELANGGAN PADA TOKO MODERN INDOMARET KECAMATAN SUKUN KOTA MALANG
}

\author{
Sri Wilujeng \\ Email: media_myajeng@yahoo.co.id \\ Mohammad Fakhruddin Mudzakkir \\ Email: fakhruddin@unikama.ac.id
}

\begin{abstract}
Abstrak : Penelitian ini bertujuan untuk mengetahui pengaruh keragaman harga, keragaman kualitas, keragaman jenis produk, keragaman tampilan produk terhadap kepuasan pelanggan. Teknik pengambilan sampel menggunakan accidental sampling dengan jumlah responden 100 pembeli di Indomaret Kec. Sukun serta teknik menggunakan regresi linier berganda. Hasil analisis menunjukkan variabel persepsi keragaman kualitas produk dan variabel persepsi tampilan produk memiliki pengaruh yang positif dan signifikan terhadap kepuasan pelanggan Indomaret di Kecamatan Sukun Kota Malang. Variabel persepsi keragaman harga produk dan keragaman jenis produk tidak berpengaruh terhadap kepuasan pelanggan Indomaret di Kecamatan Sukun .
\end{abstract}

Kata kunci : Keragaman Harga, Keragaman Kualitas, Keragaman

Jenis Produk, Keragaman Tampilan Produk, Kepuasan Pelanggan

\section{PENDAHULUAN}

Berbicara tentang bisnis dan persaingan tidak terlepas dari keberhasilan perusahaan, karena perusahaan tidak akan berarti tanpa adanya pelanggan. Banyak perusahaan lebih banyak memanfaatkan hubungan yang kuat antara perusahaan dengan pelanggan untuk mendapatkan informasi berharga tentang bagaimana cara terbaik untuk melayani pelanggan dan menjaga mereka agar tidak berpindah ke merk yang lain. (Ndubisi 2007)

Salah satu faktor penting dalam bisnis ritel adalah tingkat keragaman jenis yang harus disediakan (stock) baik keragaman harga, kualitas, jenis maupun tampilan. Bisnis retail merupakan semua aktivitas yang melibatkan penjualan barang atau jasa pada konsumen akhir untuk dipergunakan yang sifatnya pribadi, bukan bisnis (Kotler 2000). Bisnis retail ditujukan untuk konsumen akhir sehingga pembelian barang bukan untuk dijual kembali konsekwensinya adalah barang yang dibeli tidak dalam jumlah besar oleh karena itu bisnis ritel harus memiliki keragaman atas barang.

Sri Wilujeng, adalah Dosen Prodi Manajemen FEB Universitas Kanjuruhan Malang Muhammad Fakhruddin M, adalah Dosen Prodi Manajemen FEB Universitas Kanjuruhan Malang 


\section{MODERNISASI, Volume 11, Nomor 2, Juni 2015}

Tingkat kepuasan konsumen terhadap pelayanan merupakan salah satu faktor yang penting dalam mengembangkan suatu sistem penyediaan pelayanan yang tanggap terhadap kebutuhan pelanggan, meminimalkan biaya dan waktu serta memaksimalkan dampak pelayanan terhadap sasaran. Saat konsumen merekomendasikan sesuatu, ini menunjukkan bahwa mereka menerima lebih dari sekedar nilai ekonomis yang baik dari sebuah produk.

Kepuasan merupakan perbandingan antara kinerja suatu produk dengan harapan konsumen sebelumnya. Keputusan pembelian merupakan tahap proses keputusan dimana konsumen secara aktual melakukan pembelian produk, selanjutnya dijelaskan bahwa proses pengambilan keputusan pembelian terdiri dari lima tahap: pengenalan kebutuhan, pencarian informasi, pengevaluasian alternatif, keputusan pembelian, dan perilaku setelah pembelian. Kepuasan pelanggan toko merupakan hasil dari evaluasi subyektif dimana pemilihan alternatif toko sudah sesuai atau melebihi harapan pelanggan.

Banyaknya ritel yang bermunculan saat ini, maka Indomaret sebagai salah satu toko modern yang ikut bersaing di dalamnya, harus bisa melakukan berbagai inovasi. Salah satunya dalam melakukan keragaman produk. Keragaman produk menciptakan ketersediaan barang dalam jumlah dan jenis yang sangat variatif sehingga menimbulkan banyaknya pilihan dalam proses belanja konsumen. Seringkali konsumen dalam proses belanjanya, keputusan yang diambil untuk membeli suatu barang adalah yang sebelumnya tidak tercantum dalam belanja barang. Keragaman produk merupakan daya tarik bagi konsumen terutama dapat memberikan alternatif pilihan yang lebih bervariasi.

\section{TINJAUAN PUSTAKA}

\section{Konsep Kepuasan}

Salah satu pendekatan untuk memahami perilaku konsumen adalah dengan menggunakan pendekatan rasional, (Mowen 1988). Menurut pendekatan ini awal mula proses konsumsi adalah adanya suatu masalah (gap) antara yang seharusnya dengan yang sebenarnya dialami. Ketika konsumen menyadari adanya konsumen akan mencari informasi baik secara internal maupun eksternal, berdasarkan informasi yang didapat konsumen akan berusaha membandingkan dengan berbagai pertimbangan yang didukung tingkat keterlibatan konsumen pada suatu produk. Tahap selanjutnya konsumen akan memutuskan melakukan pembelian dan mengkonsumsi produk. Adapun tahap akhir dari perilaku konsumen adalah evaluasi pasca mengkonsumsi produk. Evaluasi konsumen pasca mengkonsumsi menjadi hal yang penting karena konsumen akan membandingkan antara pengalaman mengkonsumsi produk dengan harapan konsumen sebelum mengkonsumsi. perilaku konsumen pasca mengkonsumsi menghasilkan sikap (perasaan positif atau negatif) terhadap suatu barang. Sikap positif atau negative konsumen dalam mengkonsumsi barang disebuat dengan kepuasan.

Kepuasan adalah perasaan senang atau kecewa seseorang yang berasal dari perbandingan antara kesannya terhadap hasil suatu jasa dan harapan-harapannya. Kepuasan merupakan perbandingan antara kinerja suatu produk dengan harapan konsumen sebelumnya (Engel et al. 1995). Jika kinerja berada di bawah harapan, pelanggan akan tidak puas. Jika kinerja produk melebihi harapan, maka pelanggan akan merasa amat puas atau senang atau minimal terdapat kesesuaian antara pengalaman konsumen dalam mengkonsumsi dengan harapan konsumen sebelumnya. Konsep kepuasan pelanggan sebenarnya merupakan turunan dari teori expectancy disconfirmation. Teori ini menekankan bahwa kepuasan atau 
ketidakpuasan ditentukan oleh suatu proses evaluasi pelanggan, dimana persepsi tersebut mengenai hasil suatu jasa dibandingkan dengan standar yang diharapkan oleh konsumen.(Zeithaml et al. 2006)

\section{Faktor-Faktor yang mempengaruhi Tingkat Harapan Konsumen}

Menurut (Gaspersz 2003) Faktor-faktor yang mempengaruhi harapan konsumen menurut terdiri dari:

1. "Kebutuhan dan keinginan" harapan ditentukan oleh kebutuhan dan keinginan semakin tinggi kebutuhan dan keinginan makan harapan konsumen akan tinggi, demikian juga sebaliknya.

2. Pengalaman masa lalu (terdahulu) ketika mengkonsumsi produk yang merupakan produk dari pesaing perusahaan

3. Pengalaman dari teman-teman, informasi dan cerita orang lain tentang kinerja produk juga dapat mempengaruhi tingkat harapan pelanggan, sebagai bahan pertimbangan konsumen untuk mengkonsumsi produk

4. Komunikasi melalui iklan dan pemasaran juga mempengaruhi harapan konsumen. Kampanye yang berlebihan akan meningkatkan harapan konsumen terhadap suatu produk dan jika secara actual hal tersebut tidak sesuai dengan kinerja produk maka hal ini akan dapat mengecewakan pelanggan

Faktor-faktor diatas dapat mempengaruhi tingkat harapan pelanggan dalam mengkonsumsi suatu produk, dimana tingkat harapan tersebut selanjutnya akan mempengaruhi kepuasan konsumen, dimana konsumen membandingkan tingkat harapan dengan pengalaman pasca mengkonsumsi produk. Adapun untuk mengetahui kepuasan pelanggan harus dilakukan pengukuran kepuasan terkait sikap konsumen pasca melakukan konsumsi terhadap barang dan jasa.

\section{Pengambilan Keputusan Pembelian}

Terdapat beberapa faktor-faktor yang menjadi pertimbangan konsumen untuk mengambil keputusan pembelian suatu produk, baik faktor dari dalam dirinya (psikologi) maupun diluar dirinya (sosial). Keputusan pembelian merupakan tahap proses keputusan dimana konsumen secara aktual melakukan pembelian produk, selanjutnya dijelaskan bahwa proses pengambilan keputusan pembelian terdiri dari lima tahap: pengenalan kebutuhan, pencarian informasi, pengevaluasian alternatif, keputusan pembelian, dan perilaku setelah pembelian.

Pengambilan keputusan pembelian konsumen adalah sebagai berikut (Mowen \& Minor 2002):

1. Pengenalan kebutuhan (need recognition)

Pengenalan kebutuhan merupakan tahap pertama proses keputusan pembelian dimana konsumen mengenali permasalahan atau kebutuhan. Pembeli merasakan adanya perbedaan antara keadaan aktual dan sejumlah keadaan yang diinginkan.

2. Pencarian informasi

Pencarian informasi merupakan tahap proses pengambilan keputusan pembeli dimana konsumen mencari informasi tambahan, yang bertujuan untuk sekedar mencari informasi tambahan atau mencari informasi secara aktif baik di dalam dirinya maupun diluar dirinya.

3. Pengevaluasian alternative 
96 MODERNISASI, Volume 11, Nomor 2, Juni 2015

4. Pengevaluasian alternatif merupakan tahap proses keputusan pembeli dimana konsumen menggunakan informasi mempertimbankan berbagai merek alternatif di dalam serangkaian pilihan yang ada.

5. Menentukan pembelian Merupakan aktifitas aktual konsumen untuk menentukan produk yang dibeli.

6. Perilaku setelah pembelian

Perilaku setelah pembelian merupakan tahap proses keputusan pembeli konsumen tindak lebih lanjut setelah pembelian berdasarkan evaluasi setelah melakukan konsumsi

\section{Produk}

Pengertian produk merupakan segala sesuatu yang ditawarkan ke pasar untuk memuaskan kebutuhan dan keinginan atau kebutuhan, (Kotler 2000). Produk senantiasa dikembangkan untuk memberikan kepuasan pada konsumen, sehingga selalu dikembangkan dalam rangka mencapai tujuan dibuatnya produk tersebut.

Terdapat tingkatan produk yang dikategorikan menjadi lima tingkatan, (Kotler 2000) yaitu :

1. Manfaat Inti (Core Benefit)

Manfaat inti merupakan tingkatan yang paling dasar dari tingkatan produk dan berisikan manfaat atau jasa inti yang sebenarnya dibeli oleh konsumen.

2. Produk Generik (Generic Product)

Produk generik merupakan manfaat umum yang diperoleh para konsumen dari produk yang dikonsumsinya.

3. Produk Yang Diharapkan (Expected Product)

Yaitu serangkaian atribut dan kondisi yang biasanya diharapkan oleh pembeli ketika membeli produk tersebut.

4. Tambahan Produk (Augmented Product)

Adalah adanya manfaat tambahan yang ditawarkan untuk memberikan kepuasan kepada konsumen.

5. Produk Potensial (Potential Product)

Merupakan produk yang secara potensial mempunyai manfaat untuk dikonsumsi (mencakup semua peningkatan transformasi yang pada akhirnya akan dialami oleh produk tersebut dimasa depan).

\section{Keragaman Produk}

Keragaman produk merupakan kumpulan seluruh produk dan barang yang ditawarkan penjual tertentu kepada pembeli (Kotler 2000). Keragaman produk menciptakan ketersediaan barang dalam jumlah dan jenis yang sangat variatif sehingga menimbulkan banyaknya pilihan dalam proses belanja konsumen. Seringkali konsumen dalam proses belanjanya, keputusan yang diambil untuk membeli suatu barang adalah yang sebelumnya tidak tercantum dalam belanja barang.

Keragaman produk merupakan daya tarik bagi konsumen terutama dapat memberikan alternative pilihan yang lebih bervariasi. Alternative pilihan yang lebih bervariasi bagi konsumen dapat mendorong kepuasan konsumen. (Botti \& Iyengar 2006)

Beberapa peneliti sebelumnya menjelaskan hubungan product assortment. Product assortment berhubungan dengan kebebasan untuk memilih barang, (Berkowitz et al. 1980), Sedangkan (Brown 1969) menjelaskan bahwa product assortment memberikan kesempatan seseorang untuk berekspresi. Adapun bagi pengecer keragaman jenis produk dapat dimanfaatkan sebagai strategi diferensiasi 
toko dibandingkan dengan pesaing, disamping meningkatkan biaya terutama biaya persediaan.

Keragaman produk merupakan persepsi konsumen yang dibagi menjadi beberapa dimensi penting yang meliputi : keragaman harga produk, keragaman kualitas produk, keragaman jenis produk dan keragaman tampilan produk. (Zielke 2010).

1. Persepsi keragaman harga produk

Merupakan penilaian konsumen terhadap berbagai harga produk yang ditawarkan pada berbagai tingkat kategori.

2. Keragaman kualitas produk

Merupakan penilaian konsumen terhadap berbagai kualitas produk yang ditawarkan pada berbagai kategori.

3. Keragaman jenis produk

Merupakan penilaian konsumen terhadap berbagai jenis produk yang ditawarkan pada berbagai kategori

4. Keragaman tampilan produk.

Merupakan penilaian konsumen terhadap tampilan produk yang ditawarkan pada berbagai kategori

\section{Kerangka Konsep Penelitian}

Berdasarkan uraian di atas maka dalam penelitian ini disusun kerangka konseptual sebagai berikut:

Gambar 1

Kerangka Konsep Penelitian

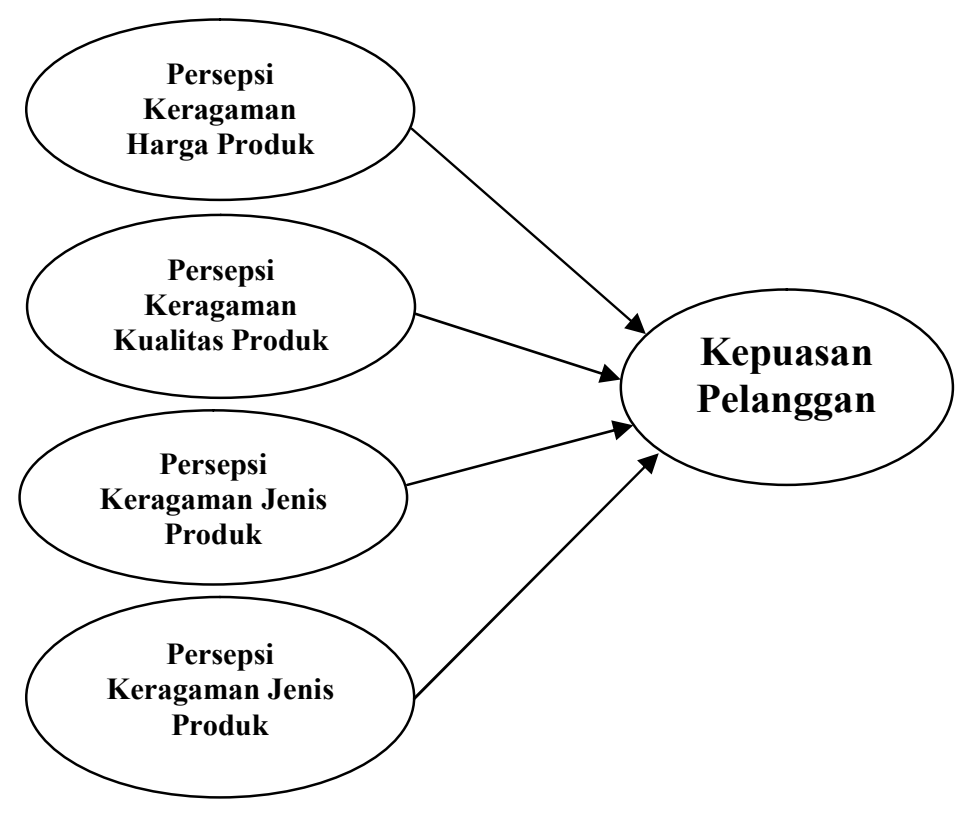


98 MODERNISASI, Volume 11, Nomor 2, Juni 2015

\subsection{Hipotesis Penelitian}

Berdasarkan kajian teoritis dan penelitian-penelitian terdahulu, maka dalam penelitian ini disusun hipotesis penelitian sebagai berikut:

H1. Semakin kuat persepsi keragaman harga produk maka semakin kuat kepuasan produk

H2. Semakin kuat persepsi keragaman kualitas produk maka semakin kuat kepuasan produk

H3. Semakin kuat persepsi keragaman jenis produk maka semakin kuat kepuasan produk

H4. Semakin kuat persepsi keragaman tampilan produk dan maka semakin kuat kepuasan produk

\section{METODOLOGI PENELITIAN}

Populasi penelitian adalah pelanggan Indomaret di wilayah Kecamatan Kota Malang. Metode pengambilan sampel adalah non probability sampling dimana jumlah anggota populasi tidak dapat diketahui dengan pasti. Adapun teknik pengambilan sampling menggunakan teknik accidental sampling.

Metode pengumpulan data menggunakan kuesioner, yang dirancang dalam bentuk kuesioner tertutup. Kuesioner tertutup digunakan untuk mengukur tentang persepsi keragaman harga, persepsi keragaman jenis, persepsi keragaman kualitas, persepsi keragaman tampilan produk dan kepuasan pelanggan Selain itu dalam penelitian ini dilengkapi dengan wawancara, digunakan untuk menggali informasi yang tidak tercakup dalam kuesioner, dimana responden diminta untuk memberikan penjelasan atas pilihan jawaban dari pertanyaan yang diajukan.

\section{Definisi Operasional Variabel dan Pengukuran}

1. Persepsi keragaman harga produk

Merupakan penilaian konsumen terhadap berbagai harga produk yang ditawarkan pada berbagai tingkat kategori, dengan indikator penelitian sebagai berikut :

- Ragam harga produk yang ditawarkan di toko banyak yang murah

- Harga-harga produk di toko ini berbagai bermacam-macam (murah, harga sedang, mahal)

- Toko ini mempunyai produk yang dengan merek sendiri yang lebih murah dari pada produk merek lainnya.

2. Keragaman kualitas produk

Merupakan penilaian konsumen terhadap berbagai kualitas produk yang ditawarkan pada berbagai kategori, dengan indikator penelitian sebagai berikut :

- Toko ini menjual produk-produk yang berkualitas

- Produk yang dijual di toko ini tidak ada yang sudah expired date

- Merk produk yang dijual di toko ini merupakan merek yang terkenal

3. Keragaman jenis variasi produk

Merupakan penilaian konsumen terhadap berbagai jenis variasi produk yang ditawarkan pada berbagai kategori, dengan indikator penelitian sebagai berikut :

- Merk yang dijual di toko ini bermacam-macam 
- $\quad$ Setiap merk produk yang dijual di toko ini didukung dengan berbagai macam jenis/rasa yang berbeda

- Jenis barang yang dijual di toko ini diukung dengan berbagai ukuran (kilo, ons, dll)

- Barang yang dijual di toko ini pada berbagai tingkat kualitas (kualitas baik, kualitas sedang, kualitas kurang)

4. Keragaman tampilan produk.

Merupakan penilaian konsumen terhadap tampilan produk yang ditawarkan pada berbagai kategori, dengan indikator penelitian sebagai berikut :

- Pengelompokan jenis produk di display

- Tata letak produk-produk di toko

5. Kepuasan Pelanggan

Merupakan perilaku konsumen pasca pembelian dengan sikap puas atau tidak puas dalam mengkonsumsi barang dan jasa:

- Saya merasa puas dengan keputusan saya untuk berbelanja di toko ini.

- Keputusan saya untuk berbelanja di toko ini merupakan suatu hal yang bijaksana.

- Saya berfikir bahwa saya telah melakukan sesuatu hal yang baik ketika berbelanja di toko ini.

- Saya benar-benar nyaman ketika berbelanja di toko ini.

\section{PEMBAHASAN}

\section{Hasil Analisis Data}

Kuisioner yang akan digunakan sebagai alat pengumpul data terlebih dahulu diuji validitas dan reliabilitasnya dengan cara menghitung nilai validitas dan reliabilitasnya. Adapun hasil uji dari validitas dan reliabilitas kuesioner penelitian dapat dijelaskan sebagaimana di bawah ini.

\section{a. Uji Validitas}

Perhitungan dilakukan dengan mengkorelasikan setiap skor item dengan skor total dengan menggunakan teknik Korelasi Product Moment. Kriteria pengujian adalah jika koefisien korelasi $\mathrm{r}_{\mathrm{xy}}$ lebih besar dari $\mathrm{r}_{\text {tabel }}$ product moment berarti item kuisioner dinyatakan valid dan dinyatakan sah sebagai alat pengumpul data.

Penyebaran kuesioner penelitian dilakukan pada pelanggan Indomaret di wilayah Kecamatan Sukun Kota Malang sejumlah 90 kuesioner. Adapun kuesioner yang kembali adalah sejumlah 90 kuesioner. Dengan jumlah responden $n=90$ degree of freedom ( $n-2)$ dan taraf signifikansi $(\alpha)=0.05$ diketahui nilai $r_{\text {tabel }}=0,207$. Adapun ikhtisar hasil perhitungan $r_{x y}$ sebagaimana output Program SPSS dapat dilihat pada tabel di bawah ini.

Tabel 1

Uji Validitas Kuisioner

\begin{tabular}{|c|c|c|c|c|}
\hline Variabel & Butir & $\mathrm{r}_{\mathrm{xy}}$ & $\mathrm{r}_{\text {tabel }}$ & Keterangan \\
\hline $\begin{array}{c}\text { Persepsi Keragaman } \\
\text { Produk (X1) }\end{array}$ & $\mathrm{X}_{1-1}$ & 0.605 & 0.195 & Valid \\
\cline { 2 - 5 } & $\mathrm{X}_{1-2}$ & 0.733 & 0.195 & Valid \\
\hline
\end{tabular}


100 MODERNISASI, Volume 11, Nomor 2, Juni 2015

\begin{tabular}{|c|c|c|c|c|}
\hline Variabel & Butir & $\mathrm{r}_{\mathrm{xy}}$ & $\mathrm{r}_{\text {tabel }}$ & Keterangan \\
\hline & $\mathrm{X}_{1-3}$ & 0.709 & 0.195 & Valid \\
\hline \multirow{3}{*}{$\begin{array}{c}\text { Persepsi Keragaman } \\
\text { Kualitas Produk (X2) }\end{array}$} & $\mathrm{X}_{2-1}$ & 0.692 & 0.195 & Valid \\
\cline { 2 - 5 } & $\mathrm{X}_{2-2}$ & 0.698 & 0.195 & Valid \\
\cline { 2 - 5 } & $\mathrm{X}_{2-3}$ & 0.595 & 0.195 & Valid \\
\hline \multirow{3}{*}{$\begin{array}{c}\text { Persepsi Keragaman } \\
\text { Jenis Produk (X3) }\end{array}$} & $\mathrm{X}_{3-1}$ & 0.697 & 0.195 & Valid \\
\cline { 2 - 5 } & $\mathrm{X}_{3-2}$ & 0.761 & 0.195 & Valid \\
\cline { 2 - 5 } & $\mathrm{X}_{3-3}$ & 0.713 & 0.195 & Valid \\
\cline { 2 - 5 } & $\mathrm{X}_{3-4}$ & 0.508 & 0.195 & Valid \\
\hline \multirow{2}{*}{$\begin{array}{c}\text { Persepsi Tampilan } \\
\text { Produk (X4) }\end{array}$} & $\mathrm{X}_{4-1}$ & 0.703 & 0.195 & Valid \\
\cline { 2 - 5 } & $\mathrm{X}_{4-2}$ & 0.658 & 0.195 & Valid \\
\hline \multirow{3}{*}{$\begin{array}{c}\text { Kepuasan Pelanggan } \\
\text { (Y) }\end{array}$} & $\mathrm{Y}_{1}$ & 0.608 & 0.195 & Valid \\
\cline { 2 - 5 } & $\mathrm{Y}_{2}$ & 0.553 & 0.195 & Valid \\
\cline { 2 - 5 } & $\mathrm{Y}_{3}$ & 0.596 & 0.195 & Valid \\
\cline { 2 - 5 } & $\mathrm{Y}_{4}$ & 0.594 & 0.195 & Valid \\
\hline
\end{tabular}

Sumber : Data Diolah 2015

Atas dasar ikhtisar sebagaimana pada tabel di atas diketahui bahwa nilai $\boldsymbol{r}_{\text {hitung }}$ untuk semua variabel lebih besar dari $\boldsymbol{r}_{\text {tabel. }}$. Dengan demikian semua butir kuisioner dinyatakan valid sehingga dinyatakan baik dan layak dipergunakan sebagai alat pengumpul data.

\section{b. Uji Reliabilitas}

Pengujian realiabilitas kusioner dilakukan dengan menggunakan rumus Alpha-Cronbach. Kriteria pengujian menyebutkan apabila nilai Alpha-Cronbach lebih besar dari 0.6 maka butir kuisioner tersebut dinyatakan reliabel. Adapun rangkuman interprestasi reliabilitas kusioner sesuai dengan output SPSS dapat dilihat pada tabel di bawah ini.

Tabel 2

Ikhtisar Uji Reliabilitas Kusioner

\begin{tabular}{|c|l|c|c|}
\hline No. & \multicolumn{1}{|c|}{ Variabel } & $\begin{array}{c}\text { Koefisien } \\
\text { Alpha } \\
\text { Cronbach }\end{array}$ & Keterangan \\
\hline 1 & Persepsi Keragaman Produk (X1 & 0.728 & Reliabel \\
\hline 2 & Persepsi Keragaman Kualitas Produk (X2) & 0.711 & Reliabel \\
\hline 3 & Persepsi Keragaman Jenis Produk (X3) & 0.798 & Reliabel \\
\hline 4 & Persepsi Tampilan Produk (X4) & 0.798 & Reliabel \\
\hline
\end{tabular}

Sumber: Data Diolah 2015

Atas dasar ikhtisar kuesioner penelitian sebagaimana pada tabel di atas diketahui bahwa nilai Alpha Cronbach untuk semua variabel lebih besar dari 0,6. Dengan demikian semua butir kuesioner dinyatakan reliabel sehingga dinyatakan baik dan layak dipergunakan sebagai alat pengumpul data. 


\section{Hasil Analisis Penelitian}

1) Uji Asumsi Klasik

Tujuan penggunaan dari uji asumsi klasik adalah agar diperoleh estimator tidak bias dari regresi dengan kuadrat terkecil biasa.

a. Uji Multikolinieritas

Model regresi yang baik jika tidak terjadi hubungan antar variabel independen. Adapun kriteria pengukurannya adalah jika nilai toleransi $\leq 1$ berarti tidak ada korelasi antar variabel independen dan jika VIF tidak melebihi 10 maka model dinyatakan tidak terkena persoalan multikolonier. Adapun ikhtisar uji multikolonieritas sebagaimana output SPSS dapat dilihat pada tabel di bawah ini.

Tabel 3

Interpretasi Uji Multikolonieritas

\begin{tabular}{|l|l|c|c|l|}
\hline No & \multicolumn{1}{|c|}{ Variabel } & Tolerance & VIF & \multicolumn{1}{|c|}{ Keputusan } \\
\hline 1. & Persepsi Keragaman Produk (X1) & 0.420 & 2.378 & Tidak terjadi multikolonieritas \\
\hline 2. & $\begin{array}{l}\text { Persepsi Keragaman Kualitas } \\
\text { Produk (X2) }\end{array}$ & 0.463 & 2.159 & Tidak terjadi multikolonieritas \\
\hline 3. & $\begin{array}{l}\text { Persepsi Keragaman Jenis Produk } \\
\text { (X3) }\end{array}$ & 0.612 & 1.634 & Tidak terjadi multikolonieritas \\
\hline 4. & Persepsi Tampilan Produk (X4) & 0.609 & 0.609 & Tidak terjadi multikolonieritas \\
\hline
\end{tabular}

Sumber: Data Diolah, 2015

Dari hasil hasil uji multikolonieritas menunjukkan empat variabel bebas tidak mengalami multikolonieritas.

b. Normalitas

Model regresi yang baik jika semua variabel berdistribusi normal. Jika data menyebar di sekitar garis diagonal dan mengikuti arah garis diagonal maka model regresi memenuhi asumsi normalitas.

Gambar 2

Normal P-P Plot Uji Normalitas

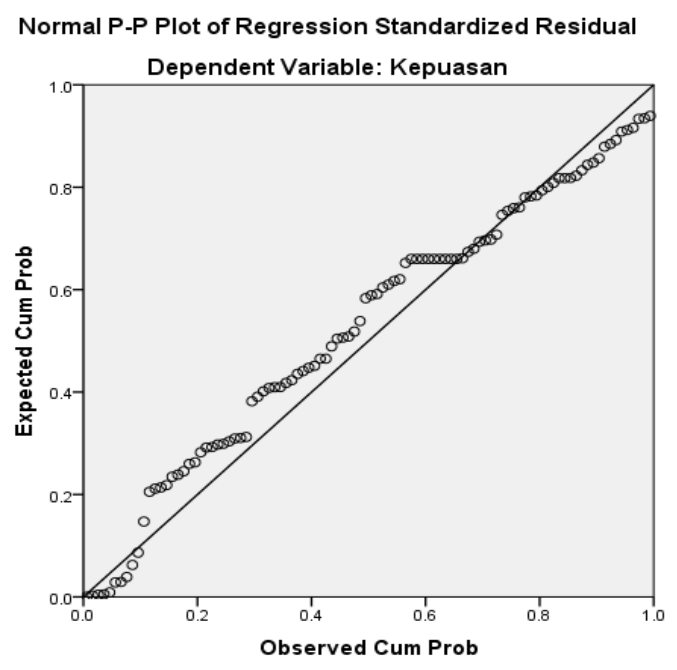


102 MODERNISASI, Volume 11, Nomor 2, Juni 2015

Atas dasar Normal P-P Plot Uji Normalitas output SPSS di atas, diketahui bahwa sebaran data yang ada menyebar di sekitar garis diagonal dan mengikuti arah garis diagonal. Dengan demikian dapat disimpulkan bahwa data mempunyai distribusi normal.

\section{2) Uji Regresi Linier Berganda}

Pengujian statistik dengan alat analisis regresi linier berganda dimaksudkan untuk mengetahui pengaruh Persepsi Keragaman Harga Produk $\left(\mathrm{X}_{1}\right)$, Persepsi Keragaman Kualitas Produk $\left(\mathrm{X}_{2}\right)$, Persepsi Keragaman Jenis Produk $\left(\mathrm{X}_{3}\right)$, Persepsi Tampilan Produk $\left(\mathrm{X}_{4}\right)$, terhadap kepuasan pelanggan (Y) Indomaret di Kecamatan Sukun Kota Malang. Adapun ikhtisar output penelitian dapat dilihat pada tabel di bawah ini.

Tabel 4

Ikhtisar Output Regresi Linier Berganda

\begin{tabular}{|c|c|c|c|c|c|}
\hline \multirow{2}{*}{$\begin{array}{l}\text { Variabel } \\
\text { Independen }\end{array}$} & \multicolumn{2}{|c|}{$\begin{array}{l}\text { Unstandardized } \\
\text { Coefficients }\end{array}$} & \multirow[t]{2}{*}{ Beta } & \multirow[t]{2}{*}{ t-hitung } & \multirow[t]{2}{*}{ Sign. $T$} \\
\hline & $B$ & Error & & & \\
\hline (Constant) & 0.455 & 1.508 & & .302 & .763 \\
\hline Keragaman_Harga (X1) & 0.217 & 0.167 & 0.142 & 1.299 & 0.197 \\
\hline Keragaman_Kualitas (X2) & 0.444 & 0.160 & 0.288 & 2.767 & 0.007 \\
\hline Keragaman_Jenis (X3) & 0.039 & 0.093 & 0.038 & 0.420 & 0.675 \\
\hline Keragaman_Tampilan (X4) & 0.766 & 0.179 & 0.388 & 4.272 & 0.000 \\
\hline $\mathrm{R}$ & $=0.723$ & & & & \\
\hline$R$ Square $\left(R^{2}\right)$ & $=0.523$ & & & & \\
\hline Adusted. $R$ Square & $=0.502$ & & & & \\
\hline $\begin{array}{l}\mathrm{F}_{\text {-hitung }} \\
\text { Sign-F}\end{array}$ & $\begin{array}{l}=25.991 \\
=0.000\end{array}$ & & & & \\
\hline \multicolumn{6}{|c|}{ Variabel Dependent $=$ Perilaku Etis } \\
\hline
\end{tabular}

Persamaan regresi linier berganda sebagai mana pada ikhtisar output SPSS adalah:

$$
\mathrm{Y}=0.455+0.217 \mathrm{X}_{1}+0.444 \mathrm{X}_{2}+0.039 \mathrm{X}_{3}+0.766 \mathrm{X}_{4}
$$

Persamaan ini menunjukkan hal-hal sebagai berikut:

(1) Konstanta sebesar 0.455 menunjukkan besarnya variabel kepuasan pelanggan jika Persepsi keragaman harga produk $\left(\mathrm{X}_{1}\right)$, Persepsi Keragaman Kualitas Produk $\left(\mathrm{X}_{2}\right)$, Persepsi Keragaman Jenis Produk $\left(\mathrm{X}_{3}\right)$, Persepsi Tampilan Produk $\left(\mathrm{X}_{4}\right)$ sebesar 0 (nol).

(2) Variabel keragaman harga produk $\left(\mathrm{X}_{1}\right)$, memiliki nilai sebesar 0.217. Hal ini menyatakan bahwa setiap satuan Variabel keragaman harga produk akan berpengaruh terhadap kepuasan pelanggan sebesar 0.217 apabila variabel lainnya tetap.

(3) Variabel Persepsi Keragaman Kualitas Produk $\left(\mathrm{X}_{2}\right)$, memiliki nilai sebesar 0,444. Hal ini menyatakan bahwa setiap satuan variabel Persepsi Keragaman Kualitas Produk akan berpengaruh terhadap kepuasan pelanggan sebesar 0,444 apabila variabel lainnya tetap. 
(4) Variabel Persepsi Keragaman Jenis Produk $\left(\mathrm{X}_{3}\right)$, memiliki nilai sebesar 0.039. Hal ini menyatakan bahwa setiap satuan Variabel Persepsi Keragaman Jenis Produk akan berpengaruh terhadap kepuasan pelanggan 0.039 apabila variabel lainnya tetap.

(5) Variabel Persepsi Keragaman Tampilan Produk $\left(\mathrm{X}_{4}\right)$, memiliki nilai sebesar 0.766. Hal ini menyatakan bahwa setiap satuan Variabel Persepsi Tampilan Produk akan berpengaruh terhadap kepuasan pelanggan 0.766 apabila variabel lainnya tetap.

\section{3) Uji Hipotesis (Uji F)}

Uji $\mathrm{F}$ digunakan untuk mengetahui pengaruh secara simultan variabel Persepsi Keragaman Harga Produk $\left(\mathrm{X}_{1}\right)$, Persepsi Keragaman Kualitas Produk $\left(\mathrm{X}_{2}\right)$, Persepsi Keragaman Jenis Produk $\left(\mathrm{X}_{3}\right)$, Persepsi Tampilan Produk $\left(\mathrm{X}_{4}\right)$, terhadap kepuasan pelanggan $(\mathrm{Y})$ Indomaret di Kecamatan Sukun Kota Malang.

Berdasarkan output SPSS nilai $\mathrm{F}_{\text {hitung }}=25.991$ dengan probabilitas 0.000 . Kriteria pengujian menyatakan jika probabilitas hitung < level of significance $(\alpha)$ maka $\mathrm{H}_{\mathrm{o}}$ ditolak atau ada pengaruh signifikan secara simultan Persepsi Keragaman Harga Produk $\left(\mathrm{X}_{1}\right)$, Persepsi Keragaman Kualitas Produk $\left(\mathrm{X}_{2}\right)$, Persepsi Keragaman Jenis Produk $\left(\mathrm{X}_{3}\right)$, Persepsi Tampilan Produk $\left(\mathrm{X}_{4}\right)$, terhadap kepuasan pelanggan (Y) Indomaret di Kecamatan Sukun Kota Malang.

Hasil pengujian menunjukkan $0.000<0.05$ atau probabilitas hitung $<$ level of significance $(\alpha)$ atau Ho ditolak. Hal ini berarti Variabel Persepsi Keragaman Harga Produk $\left(\mathrm{X}_{1}\right)$, Persepsi Keragaman Kualitas Produk $\left(\mathrm{X}_{2}\right)$, Persepsi Keragaman Jenis Produk $\left(\mathrm{X}_{3}\right)$, Persepsi Tampilan Produk $\left(\mathrm{X}_{4}\right)$, terhadap kepuasan pelanggan (Y) Indomaret di Kecamatan Sukun Kota Malang.

Atas dasar analisis $F$-test tersebut maka hipotesis penelitian yang berbunyi terdapat pengaruh signifikan secara simultan Variabel Persepsi Keragaman Harga Produk $\left(\mathrm{X}_{1}\right)$, Persepsi Keragaman Kualitas Produk $\left(\mathrm{X}_{2}\right)$, Persepsi Keragaman Jenis Produk $\left(\mathrm{X}_{3}\right)$, Persepsi Tampilan Produk $\left(\mathrm{X}_{4}\right)$, terhadap kepuasan pelanggan (Y) Indomaret di Kecamatan Sukun Kota Malang.

\section{4) Uji Hipotesis (Uji t)}

Uji t digunakan untuk menguji kebenaran hipotesis penelitian dilakukan dengan alat penguji signifikan $t$-test. Hal ini dimaksudkan untuk menguji signifikansi pengaruh secara sendiri-sendiri (parsial) variabel Persepsi Keragaman Harga Produk $\left(\mathrm{X}_{1}\right)$, Persepsi Keragaman Kualitas Produk $\left(\mathrm{X}_{2}\right)$, Persepsi Keragaman Jenis Produk $\left(\mathrm{X}_{3}\right)$, Persepsi Tampilan Produk $\left(\mathrm{X}_{4}\right)$, terhadap kepuasan pelanggan (Y) Indomaret di Kecamatan Sukun Kota Malang.

(a) Uji Signifikan t-test antara variabel variabel Persepsi Keragaman Harga Produk $\left(\mathrm{X}_{1}\right)$ terhadap kepuasan pelanggan $(\mathrm{Y})$.

Hasil analisis di peroleh nilai $t_{\text {hitung }}$ Persepsi Keragaman Harga Produk $\left(\mathrm{X}_{1}\right)$ sebesar 1.299 pada tingkat probabilitas 0.197. Kriteria pengujian jika Kriteria pengujian jika Probabilitas Hitung $<$ Level of Significance 
$(\alpha)$ maka $H_{o}$ ditolak atau ada pengaruh signifikan Persepsi Keragaman Harga Produk $\left(\mathrm{X}_{1}\right)$ terhadap kepuasan pelanggan $(\mathrm{Y})$. Hasil pengujian menunjukkan bahwa $0.197>0.05$ atau probabilitas hitung $>$ level of significance $(\alpha)$ sehingga Ho diterima. Hal ini berarti bahwa tidak ada pengaruh signifikan antara Persepsi Keragaman Harga Produk $\left(\mathrm{X}_{1}\right)$ terhadap kepuasan pelanggan (Y) Indomaret di Kecamatan Sukun Kota Malang.

(b) Uji Signifikan t-test antara Persepsi Keragaman Kualitas Produk $\left(\mathrm{X}_{2}\right)$ terhadap kepuasan pelanggan (Y).

Hasil analisis di peroleh nilai $\mathrm{t}_{\text {hitung }}$ Persepsi Keragaman Kualitas Produk $\left(\mathrm{X}_{2}\right)$ sebesar 2.767 pada tingkat probabilitas 0.007. Kriteria pengujian jika Probabilitas Hitung < Level of Significance $(\alpha)$ maka $\mathrm{H}_{\mathrm{o}}$ ditolak atau ada pengaruh signifikan Persepsi Keragaman Kualitas Produk $\left(\mathrm{X}_{2}\right)$ terhadap terhadap kepuasan pelanggan $(\mathrm{Y})$. Hasil pengujian menunjukkan bahwa $0.000<0.05$ atau probabilitas hitung $<$ level of significance $(\alpha)$ sehingga Ho ditolak. Hal ini berarti bahwa ada pengaruh signifikan antara Persepsi Keragaman Kualitas Produk $\left(\mathrm{X}_{2}\right)$ terhadap kepuasan pelanggan (Y) Indomaret di Kecamatan Sukun Kota Malang.

(c) Uji Signifikan t-test antara Persepsi Keragaman Jenis Produk $\left(\mathrm{X}_{3}\right)$ terhadap kepuasan pelanggan (Y).

Hasil analisis di peroleh nilai $t_{\text {hitung }}$ Pertanggungjawaban $\left(\mathrm{X}_{3}\right)$ sebesar 0.420 pada tingkat probabilitas 0.675. Kriteria pengujian jika Probabilitas Hitung $<$ Level of Significance $(\alpha)$ maka $\mathrm{H}_{\mathrm{o}}$ ditolak atau ada pengaruh signifikan Persepsi Keragaman Jenis Produk $\left(\mathrm{X}_{3}\right)$ terhadap kepuasan pelanggan (Y). Hasil pengujian menunjukkan bahwa $0.675>0.05$ atau probabilitas hitung $>$ level of significance $(\alpha)$ sehingga Ho diterima. Hal ini berarti bahwa tidak ada pengaruh signifikan antara Persepsi Keragaman Jenis Produk $\left(\mathrm{X}_{3}\right)$ terhadap kepuasan pelanggan (Y) Indomaret di Kecamatan Sukun Kota Malang.

(d) Uji Signifikan t-test antara Persepsi Keragaman Tampilan Produk $\left(\mathrm{X}_{4}\right)$ terhadap kepuasan pelanggan (Y).

Hasil analisis di peroleh nilai $t_{\text {hitung }}$ Persepsi Keragaman Tampilan Produk $\left(\mathrm{X}_{4}\right)$ sebesar 4.272 pada tingkat probabilitas 0.000 . Kriteria pengujian jika Probabilitas Hitung < Level of Significance $(\alpha)$ maka $\mathrm{H}_{\mathrm{o}}$ ditolak atau ada pengaruh signifikan Persepsi KeragamanTampilan Produk $\left(\mathrm{X}_{4}\right)$ terhadap kepuasan pelanggan $(\mathrm{Y})$. Hasil pengujian menunjukkan bahwa $0.000<0.05$ atau probabilitas hitung $<$ level of significance $(\alpha)$ sehingga Ho ditolak. Hal ini berarti bahwa ada pengaruh signifikan antara Persepsi Keragaman Tampilan Produk $\left(\mathrm{X}_{4}\right)$ terhadap kepuasan pelanggan (Y) Indomaret di Kecamatan Sukun Kota Malang.

\section{Pembahasan}

1) Pengaruh Persepsi Keragaman Harga Produk terhadap Kepuasan Pelanggan

Variabel persepsi keragaman produk merupakan salah satu variabel yang mempengaruhi kepuasan pelanggan. Penilaian konsumen terhadap berbagai harga produk yang ditawarkan pada berbagai tingkat kategori terdiri dari ragam harga produk yang ditawarkan di toko banyak 
yang murah, harga-harga produk di toko bermacam-macam (murah, harga sedang, mahal), dan toko mempunyai produk yang dengan merek sendiri lebih murah dari pada produk merek lainnya.

Hasil dalam penelitian ini menunjukkan bahwa persepsi keragaman produk tidak berpengaruh secara signifikan terhadap kepuasan pelanggan.

Dapat diambil kesimpulan berdasarkan hasil penelitian tersebut di atas, penilaian pelanggan Indomaret menganggap bahwa harga tidak selamanya harus memberikan bersaing atau murah, harga yang sedikit mahal namun jika diimbangi dengan manfaat lain yang dapat diperoleh oleh pelanggan maka pengaruh harga terhadap kepuasan pelanggan menjadi kurang signifikan.

\section{2) Pengaruh Persepsi Keragaman Kualitas Produk terhadap Kepuasan Pelanggan}

Variabel persepsi keragaman kualitas produk merupakan salah satu variabel yang mempengaruhi kepuasan pelanggan. Persepsi keragaman kualitas produk merupakan penilaian konsumen terhadap berbagai kualitas produk yang ditawarkan pada berbagai kategori, dengan indikator penelitian adalah toko menjual produk-produk yang berkualitas, produk yang dijual di toko tidak ada yang sudah expired date serta merk produk yang dijual di toko merupakan merek yang terkenal.

Hasil dalam penelitian ini menunjukkan bahwa persepsi keragaman kualitas harga produk berpengaruh secara positif dan signifikan terhadap kepuasan pelanggan.

Dapat diambil kesimpulan berdasarkan hasil penelitian tersebut di atas bahwa pelanggan Indomaret di Kecamatan Sukun menganggap bahwa barang yang ada di Indomaret kualitasnya bervariasi, karena setiap kategori/jenis barang barang mempunyai keragaman kualitas yang sesuai yang diharapkan dan sudah dikenal oleh pelanggan.

\section{3) Pengaruh Persepsi Keragaman Jenis Produk terhadap Kepuasan Pelanggan}

Variabel persepsi keragaman jenis produk merupakan salah satu variabel yang mempengaruhi kepuasan pelanggan. Keragaman jenis variasi produk merupakan penilaian konsumen terhadap berbagai jenis variasi produk yang ditawarkan pada berbagai kategori, dengan indikator penelitian sebagai berikut: merk yang dijual di toko bermacam-macam, setiap merk produk yang dijual di toko didukung dengan berbagai macam jenis/rasa yang berbeda, jenis barang yang dijual di toko didukung dengan berbagai ukuran (kilo, ons,dll), dan barang yang dijual di toko pada berbagai tingkat kualitas (kualitas baik, kualitas sedang, kualitas kurang).

Hasil dalam penelitian ini menunjukkan bahwa persepsi keragaman produk tidak berpengaruh secara signifikan terhadap kepuasan pelanggan. Berdasarkan hasil penelitian penilaian pelanggan terhadap keragaman jenis produk di Indomaret tidak mempunyai perbedaan dengan toko lainnya, sehingga bukan merupakan hal yang penting bagi pelanggan untuk mempengaruhi kepuasan pelanggan. 
Pesaing Indomaret yang berkategori retail modern juga mempunyai keragaman jenis barang yang serupa bahkan lebih baik dibandingkan dengan Indomaret sehingga dalam hal ini keragaman jenis barang tidak berpengaruh secara signifikan terhadap kepuasan pelanggan..

\section{4) Pengaruh Persepsi Keragaman Tampilan Produk terhadap Kepuasan Pelanggan}

Variabel persepsi keragaman tampilan produk merupakan salah satu variabel yang mempengaruhi kepuasan pelanggan. Keragaman tampilan produk. merupakan penilaian konsumen terhadap tampilan produk yang ditawarkan pada berbagai kategori, dengan indikator penelitian adalah pengelompokan jenis produk di display dan Tata letak produk-produk di toko.

Hasil dalam penelitian ini menunjukkan bahwa persepsi keragaman tampilan produk berpengaruh secara positif dan signifikan terhadap kepuasan pelanggan. Dapat diambil kesimpulan berdasarkan hasil penelitian tersebut di atas bahwa pada kepuasan pelanggan Indomaret ditentukan oleh keragaman tampilan produk. Setiap ritel modern mempunyai jenis tampilan produk yang berbeda. Pelanggan Indomaret mempunyai penilaian bahwa tampilan per kategori jenis barang dan layout barang lebih baik dibandingkan dengan pesaing sehingga memudahkan bagi pelanggan untuk memilih dan menentukan barang yang akan dibeli. Berdasarkan hasil analisis deskriptif variabel yang ada didalam keragaman produk maka keragaman kualitas produk dan keragaman tampilan produk yang paling berpengaruh terhadap kepuasan pelanggan. Walaupun demikian tidak berarti variabel dan indikator yang lain dapat diabaikan karena secara keseluruhan dari varibel dalam keragaman produk sangat diperlukan untuk dapat memberikan layanan dan kepuasan bagi pelanggan. Hasil penelitian ini pada intinya merekomendasikan bahwa terdapat hubungan yang saling terkait antara keragaman produk terhadap kepuasan pelanggan. Dengan demikian maka pihak manajemen toko harus memperhatikan dan meningkatkan kepuasan pelanggan agar dapat bersaing di tengah toko modern sejenis yang pada akhirnya akan berpengaruh terhadap keuntungan jangka panjang.

\section{KESIMPULAN DAN SARAN}

\section{A. Kesimpulan}

Berdasarkan penelitian yang telah dilakukan oleh peneliti mengenai pengaruh keragaman produk terhadap kepuasan pelanggan, maka kesimpulan penelitian ini adalah :

1. Variabel persepsi keragaman harga produk tidak memiliki pengaruh yang signifikan terhadap kepuasan pelanggan Indomaret di Kecamatan Sukun Kota Malang.

2. Variabel persepsi keragaman kualitas produk memiliki pengaruh yang positif dan signifikan terhadap kepuasan pelanggan Indomaret di Kecamatan Sukun Kota Malang.

3. Variabel persepsi keragaman jenis produk tidak memiliki pengaruh yang signifikan terhadap kepuasan pelanggan Indomaret di Kecamatan Sukun Kota Malang. 
4. Variabel persepsi tampilan produk memiliki pengaruh yang positif dan signifikan terhadap kepuasan pelanggan Indomaret di Kecamatan Sukun Kota Malang.

\section{B. Saran-saran}

Berdasarkan hasil penelitian, pembahasan, dan keterbatasan penelitian, maka dapat dikemukakan saran-saran sebagai berikut :

1. Bagi peneliti lain yang akan meneliti tentang kepuasan pelanggan yang dipengaruhi oleh keragaman produk, cakupan penelitian hendaknya diperluas sehingga hasil penelitian dapat digeneralisasi. Selain itu perlu mempertimbangkan faktor-faktor lain baik eksternal maupun internal sebagai faktor yang ikut menentukan kepuasan pelanggan.

2. Bagi perusahaan, perlu diidentifikasi lebih lanjut tentang keragaman produk agar dapat melakukan strategi diferensiasi sehingga konsumen dapat membedakan keragaman produk antar peritel.

\section{DAFTAR PUSTAKA}

Berkowitz, E.N., Walton, J.R. \& Berkowitz, E.N., 1980. Contextual Influences on Consumer Price Responses: An Experimental Analysis. Journal of Marketing Research, 17(3), pp.349-358.

Botti, S. \& Iyengar, S.S., 2006. The Dark Side of Choice: When Choice Impairs Social Welfare. Journal of Public Policy \& Marketing, 25(1), pp.24-38.

Brown, F.E., 1969. Price image versus price reality. Journal of Marketing Research, 6(2), pp.185-191.

Engel, J.F., Blackwell, R.D. \& Miniard, P.W., 1995. Consumer behavior 8 th., New York: The Dryden Press Harcourt Brace College Publishers.

Gaspersz, V., 2003. Metode Analisis Untuk Peningkatan Kualitas Terjemah, ed., Jakarta: PT Gramedia Pustaka Utama.

Kotler, P., 2000. Marketing Management Millenium, Upper Saddle River, New Jersey: A Pearson Education Company.

Mowen, J.C., 1988. Beyond Consumer Decision Making. Consumer Marketing, $5(1)$, pp.15-25.

Mowen, J.C. \& Minor, M., 2002. Consumer Behavior 5th ed., New York: Prentice Hall.

Ndubisi, N.O., 2007. Relationship Marketing and Customer Loyalty. Marketing Intelligence \& Planning, 25(1), pp.98-106.

Zeithaml, V., Bitner, M. \& Gremler, D., 2006. Services marketing: Integrating customer focus across the firm. Available at: http://library.wur.nl/WebQuery/clc/1809666 [Accessed November 30, 2015].

Zielke, S., 2010. How Price Image Dimensions Influence Shopping Intentions for Different Store Formats. European Journal of Marketing, 44(6), pp.748-770. 